\title{
The Impact of Foreign Direct Investment on Productivity of Domestic Firms: The Case of Sudanese Banking Industry
}

\author{
Nasreldin Mohamed Tomsah \\ Assistant professor \\ Economics and Business Administration College, Mashreq University -Sudan
}

\begin{abstract}
The research expands existing international business literature by exploring the impact of Foreign Direct Investment (FDI) on domestic banks. It investigates how FDI affects the productivity of domestic banks in Sudan. Many countries strive to attract foreign direct investment (FDI) hoping that knowledge brought by FDI will spillover to domestic industries and increase their productivity. In contrast with earlier literature that tried to find positive interindustry spillovers from multinationals, this study focuses on effects operating in banking industry. The analysis, based on firm-level data from Sudan, the results show evidence consistent with positive productivity spillovers from FDI taking place through contacts between foreign affiliates and their local counterparts. The data indicate that productivity spillovers are associated with foreign owned banks.
\end{abstract}

Key Words: FDI, Productivity, Foreign Bank, TIFTE, NPFTE. Sudan

\section{Introduction}

In recent years, given rapid growth and change in global pattern, definition of FDI has been broadened to include the acquisition of a lasting management interest in accompany or enterprise outside the investing firm's home country. As such, it may forms, such as direct acquisition of a foreign firm, construction of a facility, or investment of a joint venture or strategic alliances with a local firm with attendant input of technology, licensing of intellectual property, in the past decade FDI has come to play a major role in the globalization of business. Reacting to changes in technology, growing linearization of the national regulatory framework governing investment and changes in capital markets profound changes have occurred in the size, scope and methods of FDI.

There is a widely accepted proposition that FDI generates productivity gains and better performance for the domestic/host economy in addition to all the other benefits of FDI to the host country (Dunning, 1994). Extensive theoretical and empirical literatures study the extent and importance of FDI effects in terms of FDI Motives (Aitken, et al., 1999) impact on home and host countries (Lipsey, et al 2005); foreign ownership and affiliate performance in host countries (Haskell et al 2008) technological transfer and spillover effects etc. (Görg and Greenaway, 2001).

Significance of the research:

This Study explores the extent to which FDI which here is foreign banks affects local banks productivity in Sudan. In particular the research will focus on the benefits that local commercial banks get from existing of foreign banks operating in Sudan which may introduce an up-to-date banking technology and modified human resources management practices to enhance the productivity of local banks.

Many studies in literature research the theoretical roots of why foreign versus domestic-owned firms possess a superior productivity gap and test the gap empirically at different levels, mainly for manufacture industries (Goldberg and Dages 2009). But rarely any study has tested the same question in services industries. 


\section{Problem of the Research:}

The research problem central to this research focuses on whether there is impact of foreign direct investment on productivity of domestic firms, mainly the effect of foreign banks on local banks productivity, why a productivity gap between foreign owned affiliates and domestic owned firms in a host country might exist (theoretically) and to test whether such gaps exist empirically.

The main problem this research will be addressing is the impact of FDI on the Productivity of Sudanese banking industry by foreign ownership participated in the business.

\section{Objectives of the Research:}

- To investigate whether the foreign banks perform significantly better than local banks in term of productivity

- To provide useful recommendations to senior managers, investors and policy makers

Questions of the Research:

The research questions underlying this research are as follows

1-Do foreign banks perform better than domestic counterparts in productivity in term of TIFTE?

2-Do foreign banks perform better than domestic counterpart's in productivity in term of NPFTE

This research will study such questions in the Sudan context. How foreign Ownership affects the business productivity will be the focus.

Methods of Data Collection and Analysis of the Research:

1. Collecting data about the productivity in banks in terms of TIFTE

2. Collecting data about the productivity in banks in terms of NPFTE

3. Secondary data will be collected from banks audited annual reports, statements, magazines, banks union reports and bulletins.

\section{Scope of the Research}

The research will covers the commercial banks headquarters with two eligibility criteria;

1- Banks with five or more years operating in Sudan.

2- Banks' headquarters in Khartoum state.

Stratification Variable; Types of banks;

A. Domestic Banks.

Banks with majority of their shareholders being Sudanese

B. Foreign Banks,

Banks with at least 50 percent foreign owned (i.e. more than 50 percent of its share capital is owned by foreign residents) were defined as foreign banks , (Görg and Greenaway2007)

\section{The Literature Review}

Definition of Foreign Direct Investment

UNCTAD (2009) consider the threshold for control of assets as being at least $10 \%$ of the original shares or voting, for the OECD (2009), the ownership of at least 10\% implies that the investor can participate and exert influence on management without necessarily having an absolute control of the enterprise. For this reason the OECD considers that the $10 \%$ is not required as a threshold. 
Konings, (2001) define foreign direct investment (FDI) as "a firm largely owned by foreign residents acquiring or expanding a subsidiary firm or factory located in the host developing country." Krugman, Obstfeld, and Melitz consider an investment to be FDI "when a (domestic) firm buys more than 10 percent of a foreign firm, or when a firm builds a new production facility abroad." Krugman, Obstfeld, and Melitz categorize FDI as a firm having at least 10 percent ownership of the foreign firm because, at this point, the investing firm is considered to have control, or decision-making power, in the foreign company. The controlling or owning firm is known as a multinational firm while the controlled firms are called the multinational affiliates.

Haskell and Pereira (2008) identify four different categories of foreign direct investment. When a multinational firm builds a new production facility or creates a new firm in a foreign country, it is known as green field FDI, whereas brown field FDI is denoted as the acquisition or merger by a multinational firm with an already existing firm. While green field FDI implies full ownership of the multinational affiliates, brown field FDI can involve either full or only partial ownership of the multinational affiliates. The other two categories of foreign direct investment are horizontal FDI and vertical FDI. Horizontal foreign direct investment occurs when "the affiliate replicates the production process (that the parent firm undertakes in its domestic facilities) elsewhere in the world," while vertical foreign direct investment occurs when "the production chain is broken up, and parts of the production processes are transferred to the affiliate location" (Ahmed et al. (1999).

Both horizontal FDI and vertical FDI are driven by an attempt to reduce the costs of the multinational firms. Horizontal FDI takes place to reduce the costs of international trade such as transportation costs, tariffs, and quota controls by having the final production facility located in the foreign country. Vertical FDI is driven by the theory of comparative advantage. A multinational firm attempts to take advantage of abundant factors of production in a foreign country by establishing a multinational affiliate capitalizing on the abundant factors with the goal of driving down input costs of making a good or providing a service (Goldberg, 2009). The following table is a summary of the four categories of foreign direct investment:

\section{Table 1 Types of Foreign Direct Investment}

\begin{tabular}{|l|l|}
\hline Category of FDI & Summary \\
\hline Greenfield & $\begin{array}{l}\text { Building a new plant facility with full ownership of the } \\
\text { multinational affiliate by the multinational firm. }\end{array}$ \\
\hline Brownfield & Cross-border merger or acquisition by a multinational firm \\
\hline Vertical & $\begin{array}{l}\text { Partial or full ownership of a plant facility to take advantage } \\
\text { of abundant } \\
\text { factors of production }\end{array}$ \\
\hline Horizontal & $\begin{array}{l}\text { Partial or full ownership of a plant facility to avoid costs } \\
\text { associated with } \\
\text { international trade }\end{array}$ \\
\hline
\end{tabular}

\section{FDI and productivity}

The large and overwhelming strand of literature on the effect of FDI on local contexts has focused primarily on examining the spillovers effects on firm's productivity (Osman, 2010). Within this framework, the empirical literature has identified three main channels through which FDI impact on domestic-owned plants: horizontal intra-industry economic linkages, vertical upstream and vertical downstream inter-industry linkages.

The literature on productivity spillovers from inward FDI provides evidence for a number of particular countries. (Markusen (2009) uses data for 10 manufacturing sectors for 17 OECD countries, thereby providing more general evidence their results show that, on average, inward FDI is positively associated with domestic productivity at the industry level, while this relationship is negative for outward FDI. However, they also show that this result hides considerable heterogeneity in the effects across countries, 
finding a number of examples where inward FDI is negatively associated with productivity (e.g., postunification Germany, Spain, Italy and Norway), as well as countries where the relationship between outward FDI and productivity is positive(France, Poland, Sweden, UK, USA). Olley (2008) shows that only the most productive firms in a country become multinationals, whereas progressively less productive firms enter progressively more attractive countries.

Productivity spillovers take place when the entry of FDI in the host economy leads to productivity or efficiency benefits in the domestic firms and the foreign firms are not able to internalize the full value of these advantages. In addition, the productivity spillovers may take place when the entry of FDI leads to more severe competition in the host economy, which forces domestic firms to use existing technology and resources more efficiently. This kind of spillover may take place if the entry of FDI raises the competition that forces domestic firms to search for new and more efficient technologies (Griffith, 1999).When FDI affiliates are input suppliers there will be vertical FDI upstream spillovers, as they are able to provide domestic plants with more varieties and better quality intermediate inputs.

Evidence from developed-market foreign direct investment (FDI) flows to emerging markets suggests that foreign ownership is associated with improvements in plant productivity.

\section{Development of banking industry in Sudan:}

The traditional banking system was inherited from the Anglo-Egyptian condominium (1899-1955). When the National Bank of Egypt opened in Khartoum in 1901, it obtained a privileged position as banker to and for the government, a "semi-official" central bank. Other banks followed, but the National Bank of Egypt and Barclays Bank dominated and stabilized banking in Sudan until after World War II. Post-World War II prosperity created a demand for an increasing number of commercial banks.

Before Sudanese independence, there had been no restrictions on the movement of funds between Egypt and Sudan, and the value of the currency used in Sudan was tied to that of Egypt. This situation was unsatisfactory to an independent Sudan, which established the Sudan Currency Board to replace Egyptian and British money. It was not a central bank because it did not accept deposits, lend money, or provide commercial banks with cash and liquidity. In 1959, the Bank of Sudan was established to succeed the Sudan Currency Board and to take over the Sudanese assets of the National Bank of Egypt. In February 1960, the Bank of Sudan began acting as the central bank of Sudan, issuing currency, assisting the development of banks, providing loans, maintaining financial equilibrium, and advising the government.

Banks were nationalized in 1970 but in 1974, foreign banks were allowed to open branches in Sudan. Banks are required to maintain $20 \%$ of total deposits as a statutory reserve with the central bank. They must also direct to the agricultural sector $40 \%$ of the funds that they have for lending under the new credit ceilings. Currently there are about 37 banks with total capital of over US\$900 million.

Research Hypothesis

Following the research works by Hasan et al (2000, 2003), Haskell et al (2008) who defined two Productivity measure ratios as Total income per full time employee (TIFTE) and Net profit per full time employee (NPFTE), for the purpose of this research and statistic tests, hypotheses of this research were developed as follows;

H01-Foreign banks does not perform better than their domestic counterparts in productivity in term of total income per full time employee (TIFTE).

H11 Foreign banks perform better than their domestic counterparts in productivity in term of total income per full time employee (TIFTE).

H02- Foreign banks does not perform better than their domestic counterparts in productivity in term of net profit per full time employee (NPFTE). 
H12-Foreign banks perform better than their domestic counterparts in productivity in term of total income per full time employee (TIFTE).

\section{Methods of Data Collection and Sources:}

Primary data were collected from banks audited annual reports, statements, whereas Secondary data were collected from magazines, banks union reports and bulletins for the period from $2012-2017$. Collecting primary data about the productivity in banks using two financial ratios:

-Total income per full time employee (TIFTE).

-Net profit per full time employee (NPFTE).

Primary sampling units are the commercial banks headquarters with two eligibility criteria;

3- Banks with five or more years operating in Sudan.

4- Banks' headquarters in Khartoum state.

Stratification Variable; Types of banks;

A. Domestic Banks.

Banks with majority of their shareholders being Sudanese

B. Foreign Banks,

Lensink and Hermes (2001) define foreign firms as 100\% foreign-owned firms and domestic firms as $100 \%$ domestic-owned firms.

Banks with at least 50 percent foreign owned (i.e. more than 50 percent of its share capital is owned by foreign residents) were defined as foreign banks, Zajc (2002).

According to the Central Bank of Sudan (CBOS) definition, the foreign bank is the bank with majority of ownership is foreign.

For the purpose of this study a bank with more than 50 percent foreign ownership is a foreign bank.

\section{Results of the Hypothesis Test:}

Testing the hypotheses in accordance with the contribution of independent variables towards dependent variable Test and P-value analysis is used.

The hypothesis in this study states the following:

H01-Foreign banks does not perform better than their domestic counterparts in productivity in term of Total income per full time employee (TIFTE).

H11-Foreign banks perform better than their domestic counterparts in productivity in term of Total income per full time employee (TIFTE).

H02- Foreign banks does not perform better than their domestic counterparts in productivity in term of net profit per full time employee (NPFTE).

H12- Foreign banks perform better than their domestic counterparts in productivity in term of net profit per full time employee (NPFTE).

Table No. (2): Difference between local bank\& foreign bank in Productivity in terns of TIFTI \& NPFTE

\begin{tabular}{|c|c|c|c|c|c|}
\hline Group & Test & Mean & $\begin{array}{c}\text { Std. } \\
\text { Deviation }\end{array}$ & T-value & P-value \\
\hline \multirow{2}{*}{ TIFTI } & Local & 9.233 & 11.729 & -5.344 & 0.000 \\
\cline { 2 - 6 } & Foreign & 10.387 & 5.569 & & \\
\hline \multirow{2}{*}{ NPFTE } & Local & 5.447 & 6.068 & -7.344 & 0.000 \\
\cline { 2 - 4 } & Foreign & 9.253 & 4.871 & & \\
\hline
\end{tabular}


The above table represents that:

1. The P-value of T-test (0.000) is less than significant level (0.05) that mean there is statistical difference between local bank and foreign bank in TIFTI for foreign bank. Which indicates that local banks are perform better than the local banks in productivity in term of TIFTI. Accordingly the null hypotheses should be rejected and the alternate hypotheses should be accepted.

2. The P-value of T-test (0.000) is less than significant level (0.05) that mean there is statistical difference between local bank and foreign bank in NPFTE for foreign bank. Which indicates that local banks are perform better than the local banks in productivity in term of NPFTE. Accordingly the null hypotheses should be rejected and the alternate hypotheses should be accepted.

\section{Discussion and Conclusion;}

The objective of the study was to investigate the extent that foreign banks operated in Sudan are perform better than local banks in productivity in terms of TIFTE and NPFTE. Data analysis and interpretation revealed the following major findings under this objective.

The finding in this research indicates that there is positive correlation between TIFTE and NPFTE of foreign banks and NIFTE and NPFTE of local banks for foreign banks.

This result consist with results obtained by outcomes of Griffith, et al (2004). Haskell (2008), who examine the relationship between foreign ownership and productivity, paying particular attention to the role of MNCs in service sectors. They find in both manufacturing and service sector, multinational establishments are more productive than those domestically owned firms.

The result are consistent with the previous findings in the literature, suggesting that foreign affiliates in a host country perform better in productivity than local firms theoretically and empirically .

\section{Contributions of the Research}

This research contributes to the field of international business and finance investigating. how foreign ownership affects firm productivity has important policy implications for governments worldwide, which spend considerable resources on incentive programs aimed at attracting FDI in hopes of reaping the benefits of globalization and upgrading domestic competition in order to promote economic growth eventually.

\section{Implications of the Research}

Theoretical implications and managerial implications of research findings are discussed below:

The effect of FDI on firm productivity has long been issue of interest for academics and policy-makers. It is widely accepted that FDI plays an important role for economic growth and development, particularly in a large sized country with a potential natural resources like Sudan, who relies on the injection of foreign capitals.

Investigating how foreign ownership affects firm productivity has important policy implications for governments worldwide, which spend considerable resources on incentive programs aimed at attracting FDI in hopes of reaping the benefits of globalization and upgrading domestic competition in order to promote economic growth eventually.

In order to formulate their policies, this study can be of benefit to officials with more emphasis on productivity. This issue is of great magnitude because a developing country like Sudan will have to operate with emphasis on very high productivity in order to combat the challenges of today's global village.

Limitations for the Research

- The sample included only the commercial banks operated in Sudan located in Khartoum state before to 2017. 
-The study also was exclusive to the FDI impacts on one type of banks (commercial) and only one sector (financial sector).

\section{Directions for future Research}

- Use different bank types such as the Islamic banks or different sectors such as the agricultural, mining, petroleum or education sector

- Population of the study can be the foreign and local commercial banks throughout Sudan not only the capital of Sudan and to be subjected to different cultures. It would be a great advantage to make comparative study with the different bank types, different sectors, or with other countries.

- Other possible factors might explain causes and determinants of spillovers other than productivity gap, such as host country conditions, industrial market structure, technological sophistication and overall economic size.

Conclusions

This research is an attempt to enhance the understanding of FDI entry in Sudan and it is impacts on productivity of domestic firms. Alongside, the research has investigated productivity of foreign and domestic commercial banks in Sudan.

According to the review of FDI impact on host country and evidence presented, several aspects are of interest for economic policy. Government should continue providing incentives, to encourage inward FDI, in order to bring additional capital, technology and market access into local market, especially for Sudan, a large promising country located into a hub of the African content.

Finding in this study supported foreign owned firms have a higher productivity than local firms. Attracting more FDI is in hope of increasing overall productivity for the country through competition and spillovers. However, government policy would be wise to enact such policy to maximize benefits and minimize potential harms to local industry.

\section{References}

[1] Ahmed, A. M. \& Khababa, N. (1999): "Performance of the banking sector in Saudi Arabia", Journal of Financial Management Analysis, Volume 12, number 2, Pp. 30 - 36.

[2] Aitken, B. J. and Harrison, A. E. 1999. Do domestic firms benefit from direct foreign investment? Evidence from Venezuela. American Economic Review, 893: 605-18. [Google Scholar]

[3] Blomström, M. and Kokko, A. 2001 The economics of foreign direct investment incentives. NBER Working Paper No. 9489. [Google Scholar]

[4] Dages, B. G., Goldberg, L. and Kinney, D., 2000. Foreign and Domestic Bank Participation in Emerging Markets: Lessons from Mexico and Argentina. Federal Reserve Bank of New York Economic Policy Review, 6(3), 17-35.

[5] Djankov, S. and Hoekman, B. 2000. Foreign investment and productivity growth in Czech enterprises. World Bank Economic Review, 141: 49-64. [Google Scholar]

[6] Claessens, Stijn and Jong-Kun Lee, 2003, "Foreign Banks in Low-Income Countries: Recent Developments and Impacts," in James Hanson, Patrick .

[7] Görg, H. and Greenaway, D. 2007. Much ado about nothing? Do domestic firms really benefit from foreign direct investment? Discussion Paper No.944. Bonn: IZA. [Google Scholar]

[8] Greenaway, D. 1992. Trade related investment measures and development strategy. Kyklos, 45: 139-60. [Google Scholar]

[9] Griffith, R. 1999. Using the ARD establishment level data to look at foreign ownership and productivity in the UK. Economic Journal, 109: F416-F42. [Crossref], [Google Scholar]

[10] Haskell, J. E., Pereira, S. C. and Slaughter, M. J. 2008. Does inward foreign direct investment boost the productivity of domestic firms? NBER Working Paper No. 8724. [Google Scholar]

[11] Hasan, I., Lozano-Vivas, A. and Pastor, J. T., 2000. Cross-Border Performance in European Banking. Bank of Finland Discussion Papers, 24/2000. Bank of Finland, Helsinki. 
[12] Konings, J. 2001. The effects of foreign direct investment on domestic firms: evidence from firm level panel data in emerging economies. Economics of Transition, 9: 619-33. [Crossref], [Web of Science ${ }^{\circledR}$ ], [Google Scholar]

[13] Lensink, R., Hermes, N., 2003. The short-term effects of foreign bank entry on domestic bank behaviour: Does economic development matter? Journal of Banking and Finance, in print

[14] Lipsey, R. E. and Sjöholm, F. 2005. "The impact of inward FDI on host countries: why such different answers?". In Does foreign direct investment promote development?, Edited by: Moran, T. H., Graham, E. M. and Blomström, M. Washington, DC: Institute for International Economics. [Google Scholar]

[15] Markusen, J. R. 1995. The boundaries of multinational enterprises and the theory of international trade. Journal of Economic Perspectives, 9: 169-89. [Crossref], [Web of Science ®], [Google Scholar]

[16] Markusen, J. R. and Venables, A. J. 1999. Foreign direct investment as a catalyst for industrial development. European Economic Review, 43: 335-56. [Crossref], [Web of Science ®], [Google Scholar]

[17] Moulton, B. R. 1990. An illustration of a pitfall in estimating the effects of aggregate variables on micro units. Review of Economics and Statistics, 722: 334-38. [Google Scholar]

[18] Olley, G. S. and Pakes, A. 2008. The dynamics of productivity in the telecommunications equipment industry. Econometrica, 646: 1263-97. [Google Scholar]

[19] Osman, C. 2010. Policy Competition for Foreign Direct Investment: A Study of Competition among Governments to Attract FDI, Paris: OECD. [Crossref], [Google Scholar]

[20] Smarzynska- Javorcik, B. 2004. Does foreign direct investment increase the productivity of domestic firms? In search of spillovers through backward linkages. American Economic Review, 943: 605-27. [Google Scholar]

[21] UNCTAD. 2009. World Investment Report 2009. The Shift towards Services, New York and Geneva: UNCTAD. [Google Scholar]

[22] Zajc, P., 2002. The effect of foreign bank entry on domestic banks in Central and Eastern Europe. Paper for SUERF colloquium, 2003, 19 p. 